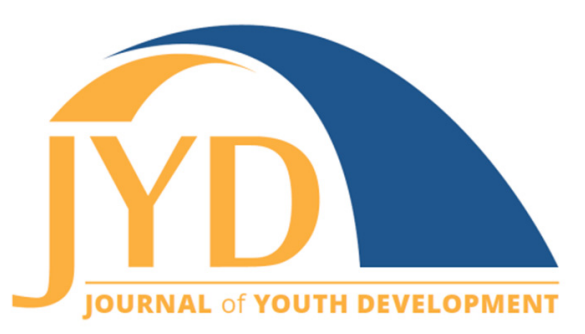

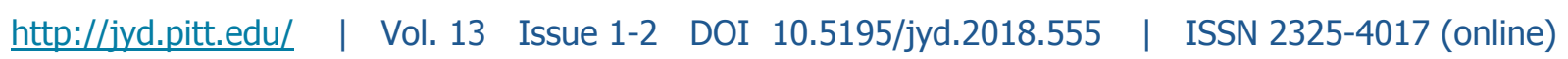

\title{
Race-Evasiveness among Camp Staff
}

\section{S. Cole Perry}

Independent Scholar

drcoleperry@gmail.com

\begin{abstract}
Camp staff have hope that summer camp plays a role in helping youth bridge differences. Educational research, though, raises concerns about preparing youth workers to combat racism (Jupp, Berry, \& Lensmire, 2016). This study draws on prior school research and critical Whiteness studies to examine race-evasiveness among camp staff. Grounded theory analysis resulted in two major thematic categories of discursive strategies by which camp staff evaded critical engagement with antiracist discussion. First, camp staff upheld dominant racial understandings by invoking discourses of colorblindness and humanist caring. Second, they prioritized White comfort by neglecting youth of color and employing selfprotective emotional tools of Whiteness (Picower, 2009). The research suggests areas of attention for scholars and camp staff trainers with regard to White staff's race-evasiveness.
\end{abstract}

Key words: critical whiteness studies, summer camp, race-evasiveness

\section{Introduction}

School research points to the difficulties of preparing American youth workers to deal with racism. An active body of White teacher identity research documents the complexities and contradictions of educators' understandings of race (Crowley, 2016; Jupp, Berry, \& Lensmire, 2016). This study examined how camp staff's conversations about racism and justice on the job functioned in ways that avoided direct challenges to White supremacy.

\section{Theory and Methods}

Critical Whiteness Studies and White teacher identity studies frame this research. A key tenet in these traditions, both undergirded by Critical Race Theory (CRT), is that racism and White supremacy are deeply ingrained in American society, including its educational institutions

(cc) EY New articles in this journal are licensed under a Creative Commons Attribution 4.0 License. This journal is published by the University Library System, University of Pittsburgh and is cosponsored by the University of Pittsburgh Press. The Journal of Youth Development is the official peer-reviewed publication of the National Association of Extension 4-H Agents and the National AfterSchool Association. 


\section{Race-Evasiveness among Camp Staff}

(Ladson-Billings, 2009; Ladson-Billings \& Tate, 1995). Moore's (2002, 2003) critically-oriented camp research documented various arrangements of White racial hegemony within kids' peer cultures. This paper is based on my study that looked specifically at camp staff. Drawing on Whiteness studies in schools, I examined how camp staff avoid confronting racism when they talk about race, that is, how they engage in race-evasiveness.

This study is part of a larger activist intervention project in which I facilitated antiracist trainings and discussions among camp staff from counselors to executives. Like McIntyre's (1997) similar project with teachers, I sought both to effect change among staff and to derive scholarly knowledge about racial understandings from these encounters. I am a White camp professional, scholar, and classroom educator. The camp where I grew up and still work is also predominantly White. The context for the conversations about race and camp in this study was workshops I gave at four camp conferences around the country. The workshops consisted, on the one hand, of snapshots of racism from my own camp contexts, ranging from the level of the interpersonal to that of institution and industry. I gave these presentations-designed to illustrate connections among racism in society, schools, and camps-and interspersed with them time for discussion, collective analysis, and brainstorming in small groups. I facilitated and participated some in each group. I understood the majority of people to be White but did not ask.

Detailed ethnographic notes from my perspective as participant-observer in these discussions and the subsequent analyses constituted the data that informed my conclusions. Specifically, I collected the responses of camp staff that were least compatible with CRT and used constant comparative methods (Corbin \& Strauss, 2008) to begin to categorize them. Further analysis of the responses-first developing theoretical sensitivity (Charmaz, 2014) to the literature analyzing teachers' race talk-resulted in clusters that served similar ideological or discursive purposes. A number of these clusters fit into the two emergent categories (Charmaz, 2014), which I describe in the remainder of this article, and the rest were not considered in this study. To strengthen the trustworthiness of this qualitative process, I discussed notes and insights with other race theorists and activists and composed theoretical memos to refine my conceptualizations of the data. Recurrent consultation of academic literature further developed insight and instrumental utility (Eisner, 1991). I consider mine to be preliminary work linking the camp context to the well-developed theorization of Whiteness and race-evasiveness among teachers in schools. 


\section{Race-Evasiveness among Camp Staff}

\section{Results}

In examining the significance of camp staff's race talk, my analyses settled on two major thematic categories. These two sets of discursive strategies constituted ways in which camp staff enacted race-evasiveness. The first category, upholding dominant racial ideas, was reflected in commitments to sustaining hegemonic understandings of race and racism. The second, prioritizing White comfort, consisted of ways camp staff signaled their concern with putting White people at ease. Both represented ways that, in discussion, camp staff evaded critical engagement with race and racism.

\section{Upholding Dominant Racial Ideas}

Researchers have documented a variety of discourses about race that teachers use and that bolster hegemonic racial ideologies (Amos, 2011; Picower, 2009; Solomon, Portelli, Daniel, \& Campbell, 2005). Upholding dominant racial ideas inhibits teachers and youth workers from challenging racism in classrooms, in curricula, and in their own contexts and lives (King \& Chandler, 2016). A common ideological framework I encountered among camp staff was colorblindness. Colorblindness, or colorblind racism, is a way of talking about race to "misrepresent the world [and] hide the fact of dominance" (Bonilla-Silva, 2003, p. 26). In my study, colorblindness manifested as challenging accounts of racism, refusing to see racism's workings, and proposing nonracial solutions to racial problems.

In order to not see racism, staff challenged others' sightings. For example, while describing a situation where a White boy pointedly ignored only his Black cabin mate, a camp professional offered that maybe the former did not hear. In another case, statistics about racial disparities in my camp's expulsion rates were challenged as "overstated" and unrepresentative. Either of these situations could be considered reasonable skepticism but are interpreted here in light of their use in racial discussions. Specifically, these two instances patterned with others in ways that dismissed harm to people of color or defended imagined intentions behind harmful actions.

Another way to be colorblind was by refusing to see the particular formations that racism took. For example, some camp staff brought up other dimensions of oppression in a manner that derailed a focus on racism. One camp worker used a common color trope, "I don't care if you're black, brown, green, or purple [it's not okay to be targeted in a dodgeball game]." While most people would agree that no child should be targeted, the trouble with this statement was that it dismissed the specific context in which a large group of White children targeted the only two 


\section{Race-Evasiveness among Camp Staff}

campers of color. This response also ignored how anti-Black racism is a pervasive pattern in society that embeds itself in Black youths' life experiences, in contrast with transient targeting that any kid might experience at some point. When applied to two Black boys who were also getting jeered at for trying to stay in the game, a nonracial reading is deficient.

Another staff member diverted the focus of analysis to seemingly related topics, as Gay and Kirkland (2003) saw among teachers. This camp director equated "teasing because somebody has glasses or is fat" with a racial microaggression and explicitly suggested the discussion group was "making too much" of the incident. This assertion had the effect not only of devaluing our efforts to understand and address how racism works but also foreclosing on the specificity of racism as a system of power in society. Bringing up vision ("glasses") and body size ("fat") did not invite intersectional analysis of how race and disability operate in tandem to create hierarchies and affect identities differentially. Instead, the notion that any differences can be weaponized in comparable ways problematically individualized the structural and institutional nature of racism as a system.

Similarly, two brief examples referenced the discredited but dominant idea of reverse racism (Pincus, 2003). One camp staff member made reference to prejudice and stereotypes "coming from all directions." Another staff person brought up a story to showcase a Black camper's racial prejudice using the word "cracker" to tease a White camper. This person commented that kids besides White ones can discriminate. The false equivalence deflected the idea that structural racism is premised on anti-Blackness and pro-Whiteness.

In more than one training, examples of racist microaggressions prompted calls for White aggressors to be generically kinder. Camp staff put forward micro-level, interpersonal solutions even as the discussion progressed to institutional and systemic analyses of racism (e.g., discipline policies and practices with disparate impacts or industry-wide barriers to access). "Empathy" and "understanding" were common refrains but are inadequate outside of a critical understanding of race and racism (Delgado, 1997). By suggesting racism is not different from meanness and that kids should just be kinder, camp staff members ignored the racialized nature of specific conflicts and the systemic nature of racism. Picower (2009) noted that a suggestion of "treating others well or [saying] 'just be nice' served to create an individual response to institutional and societal issues" (p. 208). Staff did not appear to have much of a foundation for structural or institutional analyses and instead shifted the conversation to a particular type of colorblindness. These responses and reactions of the camp staff, moreover, served a social and discursive function. They obscured the role of race and racism at camp. 


\section{Race-Evasiveness among Camp Staff}

\section{Prioritizing White Comfort}

It is well documented how White people's emotions are re-centered and given primary importance in a variety of contexts (DiAngelo, 2011; DiAngelo \& Allen, 2006). The other prevalent type of discursive strategy among camp staff was to prioritize White people's comfort. For the camp staff I spoke with, this strategy looked like considering White youth first, neglecting youth of color, and using emotional tools of Whiteness (Picower, 2009) to evade responsibility or guilt.

\section{Considering White Youth First and Neglecting Youth of Color}

One vignette that camp staff heard involved a camper bystander calling out a White boy's racism in using a racialized nickname. A training attendee said she would respond by chiding, not the White boy, but the bystander who spoke up, because it was "not nice" to refer to the nickname as racist. This response not only negated the bystander's antiracist action but also gave primary importance to the White aggressor's feelings. Researchers have recorded similar commitments to protecting White feelings at the expense of clear and compelling challenges to White supremacy (DiAngelo \& Sensoy, 2014).

A similar focus on White comfort was evident when camp staff discussed their responses to White youth after racist incidents. Racist microaggressions were viewed as teachable moments for White youth and camp staff consistently expressed a desire not to label White campers as racist. When staff brought up how they would respond to youth of color, their first inclination often diminished or punished these campers' reactions to racism. Just as in the previous example-where a camp administrator proposed intervening to correct the boy who called out the racism, but not the boy who used a racist nickname-some staff members' instincts would have the effect of compounding a racist situation, re-marginalizing young people of color.

\section{Emotional Tools of Whiteness}

Picower (2009) stressed that emotional tools of Whiteness, especially self-protective ones, "serv[ed] to obfuscate the concepts [under discussion]" (p. 205) and "protect dominant and stereotypical understandings of race" (p. 197). Besides defending White campers and staff in vignettes, camp staff sometimes took steps to protect their own ignorance or inaction. One camp director prioritized their own comfort in discussing possibly racist programming, asserting 


\section{Race-Evasiveness among Camp Staff}

that their approach would be characterized by the following, "If I'm doing something wrong or offensive, tell me and I'll change." This camp director recommended placing on a camper the burden of responsibility for dealing with a racist microaggression. Such racial logics, presuming good White intentions and abdicating responsibility, are also well-documented (Hytten \& Warren, 2003). This course of action, moreover, assumes no duty for racial self-education.

Many other staff framed the work of challenging racism as going above and beyond their duties, a self-protective discursive strategy that presumed their lack of involvement or responsibility. One memorable comment characterized antiracism and social justice as "some people's thing" but an area that others "just aren't that into." This framing, in neglecting the necessary role of antiracism in fulfilling positive youth development's universal promise, is tellingly dismissive. This approach leaves challenging racism up to others. Such moves to prioritize their own and others' White comfort, much like upholding dominant racial ideas, took the place of reckoning with what antiracist actions and responses might look like.

\section{Discussion}

In the course of this study, I sought to describe race-evasive discursive strategies. We can read into camp staff members' ideological maneuvering a lack of critical understanding and an absence of broader political commitments to challenge racism and White supremacy. It matters, though, if these conversations are part of long-term, continuing education and of ongoing commitment to action for camp staff. For race-evasiveness is best theorized as a symptom, not only of ideological hegemony, but also of interlocking systems of oppression in society.

\section{Implications for Researchers}

First, employing perspectives from CRT will center racial inequality in camp scholars' theorization of camps. Regarding camps and positive youth development outcomes (Garst, Browne, \& Bialeschki, 2011), it follows from CRT to ask the following questions:

- Do different populations benefit unequally from camps?

- What roles do camps and the camping industry play in relation to systemic and societal racism?

- In what ways do camps and the industry exacerbate racisim?

- In what ways do camps and the industry undermine and challenge racism? 


\section{Race-Evasiveness among Camp Staff}

Camp researchers should be on guard against dilution and depoliticization. Gillborn (2006) warns of "tinkering with the system to make its outputs slightly less awful, but leaving untouched the fundamental shape, scale and purpose of the system itself" (p. 7). CRT demands research's application to fundamental challenges to White supremacy. This application requires a cohort of critically-oriented, committed, and activist scholars.

\section{Implications for Camp Professionals}

First, this report points to the need for camp professionals' practice to be grounded in critical, systemic understandings of race, racism, and justice. Such understandings are not common in society but are even rarer among Whites who are unlikely to receive critical racial socialization (Hagerman, 2014). Besides more formal learning opportunities, though, such as readings, workshops, or classes, it is also important for White camp staff to seek out and listen to the stories that people of color tell about racism (especially in camp settings). Camp staff in general should actively unlearn the tendency to reduce race to individualistic terms. A variety of sources (academic, narrative, personal, statistical, etc.) can contribute to thorough knowledge of systemic inequality.

Second, the scope of the problem of racism demands collective work. Camp staff should address root causes of racism, not just work on individual-level symptoms like race-evasiveness. National organizations like Black Lives Matter and Showing Up for Racial Justice (SURJ) have local chapters across the country that collaborate in racial justice work and have proliferated in conjunction with the movement for Black lives. These groups can allow camp professionals to connect and learn about the needs of local families and communities through the expertise and relationships of embedded activists.

Racial justice groups, moreover, often provide critical racial education and even have youthcentered initiatives. Some may offer workshops for staff or youth. They can also help develop the antiracist skills, knowledge, and perspectives that can inform and guide camp practice. Personally, my own camp practice has benefitted from my work developing and implementing an after-school racial literacy curriculum for school-aged children under the leadership of Black Lives Matter: Cincinnati. During the school year, I get practice talking about race with young children.

Finally, membership in such groups can also aid in my final set of recommendations to camp staff, for accountability and vigilance. Accountability to antiracist activists helps keep camps' 
Journal of Youth Development | http://jyd.pitt.edu/ | Vol. 13 Issue 1-2 DOI 10.5195/jyd.2018.555

\section{Race-Evasiveness among Camp Staff}

priorities aligned with the urgencies identified by frontline community advocates. Accountability to organizers of color is especially important to White allies so that their expressions of solidarity can be consistently calibrated (Mayorga \& Picower, 2018). Commitments to antiracism can also be guided by an ethics of vigilance (Applebaum, 2013). This stance calls for camp professionals to seek out our own complicity in systemic injustice and be open to being identified as part of the problem.

Each of the above strategies is large in scale and necessarily must go on over time. However, they must begin with smaller commitments: to show up, to learn new ways of seeing, and to open ourselves and our professional lives to rigorous critique.

\section{References}

Amos, Y. T. (2011). Teacher dispositions for cultural competence: How should we prepare White teacher candidates for more responsibility. Action in Teacher Education, 33, 481-492. doi:10.1080/01626620.2011.627037

Applebaum, B. (2013). Vigilance as a response to White complicity. Educational Theory, 1, 17-34. doi:10.1111/edth.12007

Bonilla-Silva, E. (2003). Racism without racists: Color-blind racism and the persistence of racial inequality in the United States. New York, NY: Rowman \& Littlefield.

Charmaz, K. (2014). Constructing grounded theory. (2nd ed.). Los Angeles, CA: Sage.

Corbin, J., \& Strauss, A. (2008). Basics of qualitative research. (3rd ed.). Thousand Oaks, CA: Sage.

Crowley, R. (2016). White teachers, racial privilege, and the sociological imagination. Urban Education, 127. doi:10.1177/0042085916656901

Delgado, R. (1997). Rodrigo's eleventh chronicle: Empathy and false empathy. In R. Delgado \& J. Stefancic (Eds.), Critical white studies: Looking behind the mirror (pp. 614-618). Philadelphia, PA: Temple University Press.

DiAngelo, R. J. (2011). White fragility. International Journal of Critical Pedagogy, 3, 54-70.

DiAngelo, R. J., \& Allen, D. (2006). My feelings are not about you: Personal experience as a move of Whiteness. Interactions: UCLA Journal of Education and Information Studies, 2. Retrieved from: http://escholarship.org/uc/item/6dk67960

DiAngelo, R., \& Sensoy, Ö. (2014). Getting slammed: White depictions of race discussions as arenas of violence. Race Ethnicity and Education, 1Л1), 103-128, doi:10.1080/13613324.2012.674023

Eisner, E. W. (1991). The enlightened eye: Qualitative inquiry and the enhancement of educational practice. New York, NY: Macmillan. 
Journal of Youth Development | http://jyd.pitt.edu/ | Vol. 13 Issue 1-2 DOI 10.5195/jyd.2018.555

\section{Race-Evasiveness among Camp Staff}

Garst, B. A., Browne, L. P., \& Bialeschki, M. D. (2011). Youth development and the camp experience. New Directions for Youth Development 2011(130), 73-87. doi: 10.1002/yd.398

Gay, G., \& Kirkland, K. (2003). Developing cultural critical consciousness and self-reflection in pre-service teacher education. Theory into Practice, 42, 181-187.

Gillborn, D. (2006) Critical Race Theory and Education: Racism and Anti-racism in Educational Theory and Praxis. Discourse: Studies in the Cultural Politics of Education, 271): 11-32. doi: 10.1080/01596300500510229

Hagerman, M. A. (2014). White families and race: colour-blind and clour-conscious approaches to white racial socialization. Ethnic and Racial Studies, 3714), 2598-2614. doi:

10.1080/01419870.2013.848289

Hytten, K., \& Warren, J. (2003). Engaging whiteness: How racial power gets reified in education. Qualitative Studies in Education, 16, 65-89. doi:10.1080/0951839032000033509a

Jupp, J. C., Berry, T. R., \& Lensmire, T. J. (2016). Second-wave White teacher identity studies: A review of White teacher identity literatures from 2004 through 2014. Review of Educational Research, 86(4), 1151-1191. doi: 10.3102/0034654316629798

King, L., \& Chandler, P. (2016). From non-racism to anti-racism in social studies teacher education: Social studies and racial pedagogical content knowledge. In A. Crowe and A. Cuenca (Eds) Rethinking social studies teacher education in the twenty-first century pp. 3-21). New York, NY: Springer International.

Ladson-Billings, G. (2009). The dreamkeepers: Successful teachers of African American children (2nd ed.). San Francisco, CA: Jossey-Bass.

Ladson-Billings, G., \& Tate, W. F. (1995). Toward a critical race theory of education. Teachers College Record, 97, 47-68.

McIntyre, A. (1997). Constructing an image of a White teacher. Teachers College Record, 98, 653-681.

Mayorga, E., \& Picower, B. (2018). Active solidarity: Centering the demands and vision of the Black Lives Matter movement in teacher education. Urban Education, 53(2), 212-230. doi: $10.1177 / 0042085917747117$

Moore, V. A. (2002). The collaborative emergence of race in children's play: A case study of two summer camps. Social Problems, 49, 58-78. doi: 10.1525/sp.2002.49.1.58

Moore, V. A. (2003). Kids' approaches to whiteness in racially distinct summer day camps. The Sociological Quarterly, 44(3), 505-522. doi: 10.1111/j.1533-8525.2003.tb00543.x

Picower, B. (2009). The unexamined whiteness of teaching: How White teachers maintain and enact dominant racial ideologies. Race, Ethnicity, and Education, 12, 197-215. doi:10.1080/13613320902995475

Pincus, F. L. (2003). Reverse discrimination: Dismantling the myth. Boulder, CO: Lynee Rienner Press. 
Journal of Youth Development | http://jyd.pitt.edu/ | Vol. 13 Issue 1-2 DOI 10.5195/jyd.2018.555

Race-Evasiveness among Camp Staff

Quiroz-Martínez, J., HoSang, D., \& Villarosa, L. (2004). Changing the rules of the game: Youth development \& structural racism. Washington, DC: Philanthropic Initiative for Racial Equity.

Solomon, P. R., Portelli, J. P., Daniel, B. J., \& Campbell, A. (2005). The discourse of denial: How White teacher candidates construct race, racism, and "White privilege." Race, Ethnicity, and Education, 8, 147-169. doi:10.1080/13613320500110519 